\title{
THE KINETICS OF CHANGES IN KINEMATIC VISCOSITY OF ENGINE OILS UNDER SIMILAR OPERATING CONDITIONS
}

\section{KINETYKA ZMIAN LEPKOŚCI KINEMATYCZNEJ OLEJÓW SILNIKOWYCH W WARUNKACH EKSPLOATACJ**}

\begin{abstract}
The article describes the processes of degradation of five engine oils offered by different manufacturers, but belonging to the same SAE class of viscosity. The direction and intensity of changes in kinematic viscosity measured at two temperatures $\left(40^{\circ} \mathrm{C}\right.$ and $100^{\circ} \mathrm{C}$ ) have been analyzed. As part of the experiment, the changes in engine oils occurring during actual operation have been observed. The conditions of which can be described as "severe", i.e. frequent starting of the engine, short distance driving, extended engine idling. All engine oils were operated in passenger cars of a uniform fleet of 25 vehicles. Kinematic viscosity was determined in accordance with the EN ISO 3104. The obtained results have led to the development of a statistical model enabling to calculate average predictive values of kinematic viscosity for a given mileage. The results may facilitate decision-making regarding the service life of engine oils.
\end{abstract}

Keywords: degradation, engine, engine oil, kinematic viscosity, reliability, modeling, operating conditions.

\begin{abstract}
Niniejszy artykut opisuje odrębne degradacje 5 olejów silnikowych pochodzących od różnych producentów, należacych do tej samej klasy lepkościowej wg SAE. Analizowano kierunek oraz nasilenie zmian lepkości kinematycznej w temperaturze $40^{\circ} \mathrm{C}$ oraz $100^{\circ} \mathrm{C}$. W ramach zaprezentowanego eksperymentu zostaty obserwowane zmiany w olejach silnikowych wystepujace w trakcie rzeczywistej eksploatacji, w warunkach które można określić jako „trudne” tzn. częste uruchamianie silnika, jazda na krótkich odcinkach, przedlużona praca silnika na biegu jałowym. Oleje byly eksploatowane $w$ samochodach osobowych stanowiacych jednolita flotę 25 pojazdów. Lepkość kinematyczna wyznaczana była zgodnie z norma EN ISO 3104. Uzyskane zależności pozwoliły na opracowanie statystycznego modelu, umożliwiającego dokonywanie punktowych predykcji przeciętnych wartości lepkości kinematycznej dla zadanej wielkości przebiegu. Uzyskane wyniki moga okazać się pomocne podczas podejmowania racjonalnych decyzji dotyczących okresu eksploatacji olejów silnikowych.
\end{abstract}

Stowa kluczowe: degradacja, silnik, olej silnikowy, lepkość kinematyczna, niezawodność, modelowanie, eksploatacja.

\section{Introduction}

The lubricating oil, which is indispensable for the proper functioning of the engine, is subject to aging and it can be used as long as it fulfills its task properly by retaining specific physicochemical properties. The levels of specific physical and chemical properties of engine oil affect the quality and range of functions performed by the oil and, as such, they are a prerequisite for its suitability for a particular type of engine. Among the parameters and physicochemical quantity levels outlined in subject standards and literature, the preference is given to the kinematic viscosity and dynamic viscosity (some of the basic properties of fluids) $[2,4,6,10,11]$. Kinematic viscosity is always stipulated in the quality requirements relating to lubricating oils. It can increase or decrease during operation. An increase in viscosity is generally connected with progressive oxidation processes at elevated temperature, and a decrease with the shear of oil. The assessment of oil viscosity allows the user to estimate the time between oil changes.

According to the current state of knowledge, the quality of engine oil can be determined through a series of tests, which include laboratory evaluation of the physicochemical properties, as well as through assessing its particular properties which, however, entails lengthy and costly operational research $[1,3,8,13,15,16,18]$. Knowledge and un- derstanding of the characteristics of motor oils and developing effective methods of analysis enables the creation of systems of quality monitoring which may be conducted within the life cycle of the engine.

A number of studies have been conducted to scientifically measure the quality of engine oils. Inayatullah et al. [5] used the technique of acoustic emission to analyze engine oil viscosity. Karpovich et al. [7] attempted to develop a universal instrument to measure and control the quality of motor oils. Their evaluation of the quality and condition of engine oil was centered around viscosity as a key performance indicator. Agoston et al. [1], on the other hand, have focused in their research on thermal aging of engine oils. They have shown that oil evaporation and oil burning have the most significant impact on the process of aging, thus leading to the loss of its key properties, which inevitably affects the overall performance of the engine oil. Wang [14] used the road tests in the assessment of engine oils. Special sensors have been installed in three vehicles and tested during the drive. The results of the study point out three stages of engine oil degradation: 1. Good condition 2. A rapid increase in acid number 3. A rapid increase in viscosity.

Bassbasi et al. [3] proposed infrared spectroscopy to monitor and control as well as enable high-speed inspection of motor oils. Similarly, Wolak and Janocha [16] focused on the assessment of changes in physicochemical properties of engine oils, using the method of in-

(*) Tekst artykułu w polskiej wersji językowej dostępny w elektronicznym wydaniu kwartalnika na stronie www.ein.org.pl 
frared spectroscopy with the Fourier transform. Moreover, they compared the results of the traditional standardized method with the results obtained using modern equipment - FluidScan. Youngk [17] focused in his research on the impact of oil on the quality, longevity and reliability of the engine. The analysis was conducted based on a review of oils, engines and technologies, and a survey study of vehicle users. The results of these in-depth studies indicate a significant influence of oil change intervals on quality and reliability of the engine.

The aim of the present study was to examine the direction and intensity of changes in kinematic viscosity of engine oils under similar operating conditions. The obtained results have led to the development of a statistical model describing these relationships.

\section{Materials and methods}

The experimental material consisted of five engine oils offered by different manufacturers, but belonging to the same SAE class of viscosity. The oils were coded as CE, MS, ME, PS, PE; detailed specifications of which are presented in Table 1. All engine oils were operated in passenger cars of a uniform fleet of 25 vehicles. The cars were equipped with petrol engines with the displacement of $1,332 \mathrm{~cm}^{3}$.

The vehicles in the research were divided into two groups. The first group of 23 vehicles was operated in conditions that can be described as "severe", i.e. frequent starting of the engine, driving a short distance, extended engine idling. The second group consisting of 2 vehicles (PS018193 and CE017977) was operated in typical urban driving and mixed conditions. Graphical illustrations of the results including both groups of engine oils are presented below. However, the second group of vehicles has been left out in statistical analyzes due to their not meeting the prerequisite of

Table 1. Quality and viscosity classifications selected for engine oil testing.

\begin{tabular}{||c|c|c|c|c||}
\hline $\begin{array}{c}\text { Oil } \\
\text { Code }\end{array}$ & $\begin{array}{c}\text { SAE } \\
\text { Classification }\end{array}$ & $\begin{array}{c}\text { ACEA } \\
\text { Classification }\end{array}$ & $\begin{array}{c}\text { API } \\
\text { Classification }\end{array}$ & $\begin{array}{c}\text { OEM } \\
\text { Specifications }\end{array}$ \\
\hline CE & $5 \mathrm{w}-30$ & A3, C3 & SH & $\begin{array}{c}\text { VW 504 00; BMW Longlife-04; MB-Approval; 229.31/ } \\
\text { 229.51; Porsche C30 }\end{array}$ \\
\hline ME & $5 w-30$ & C2/C3 & SM/SN & $\begin{array}{c}\text { BMW: Longlife 04; MB-Approval: 229.31/229.51; } \\
\text { Chrysler: MS-11106; Porsche: C30; Chrysler: MS- } \\
\text { 11106; Peugeot/Citroën Automobiles: B71 2290, B71 } \\
\text { 2297; AvtoVAZ: Group “Luxe"; AAE: Standard STO } \\
\text { 003-05, Group B6 }\end{array}$ \\
\hline MS & $5 w-30$ & C3 & SM/SL & $\begin{array}{c}\text { General Motors Service Fill dexos2TM (license } \\
\text { number GB1A0914015); BMW Longlife 04; MB- } \\
\text { Approval 229.31/229.51; Volkswagen (petrol) 502 00 } \\
\text { / 505 00 }\end{array}$ \\
\hline PE & $5 \mathrm{w}-30$ & C2 & - & JASO - DL-1 \\
\hline PS & $5 \mathrm{w}-30$ & A3 & SM & VW 504.00-507.00 \\
\hline
\end{tabular}

Source: Own elaboration
Table 2. The number of kilometers traveled

\begin{tabular}{|c|c|c|c|c|c|}
\hline $\begin{array}{l}\text { Sample } \\
\text { Code }\end{array}$ & $\begin{array}{c}\text { Mileage - start } \\
\text { phase }[\mathrm{km}]\end{array}$ & $\begin{array}{l}\text { Mileage after } 3 \\
\text { months }[\mathrm{km}]\end{array}$ & $\begin{array}{c}\text { Mileage after } 6 \\
\text { months }[\mathrm{km}]\end{array}$ & $\begin{array}{l}\text { Mileage after } 9 \\
\text { months }[\mathrm{km}]\end{array}$ & $\begin{array}{l}\text { Mileage after } 12 \\
\text { months }[\mathrm{km}]\end{array}$ \\
\hline CE 17760 & 12858 & 4401 & 7931 & 11358 & 13220 \\
\hline CE 17943 & 14571 & 4215 & 7996 & 11450 & 13907 \\
\hline CE 17977 & 6033 & 2973 & 5640 & 8796 & 9975 \\
\hline CE 17988 & 14804 & 874 & 4350 & - & - \\
\hline CE 18716 & 9477 & 3080 & 6360 & 10009 & 12169 \\
\hline ME 17764 & 15484 & 3752 & 8593 & 11620 & 14501 \\
\hline ME 17810 & 7840 & 3350 & 5183 & 7702 & 8749 \\
\hline ME 17973 & 8015 & 2811 & 5513 & 7579 & 9029 \\
\hline ME 18345 & 9753 & 3176 & 5922 & 8196 & 9234 \\
\hline ME 18760 & 15307 & 4654 & 8641 & 12018 & 14573 \\
\hline MS 18011 & 13486 & 2205 & 5199 & 7265 & 9005 \\
\hline MS 18128 & 14571 & 1808 & 5218 & 8773 & 10803 \\
\hline MS 18361 & 14988 & 3790 & 7654 & 12331 & 14166 \\
\hline MS 18793 & 6223 & 818 & 1120 & 3240 & 6100 \\
\hline MS 18817 & 14666 & 3832 & 8037 & 11439 & 13877 \\
\hline PE 17939 & 12370 & 4180 & 8806 & 11990 & 13066 \\
\hline PE 18024 & 11694 & 3758 & 5881 & 10203 & 11748 \\
\hline PE 18207 & 12209 & 3836 & 7311 & 10663 & 13223 \\
\hline PE 18591 & 15409 & 4738 & 8697 & 13073 & 15188 \\
\hline PE18689 & 13290 & 3944 & 8749 & 13974 & 15531 \\
\hline PS 18149 & 13556 & 4269 & 8317 & 12412 & 14384 \\
\hline PS 18193 & 14457 & 5240 & 10619 & 14732 & 18211 \\
\hline PS 18597 & 15361 & 3544 & 8022 & - & - \\
\hline PS 18784 & 11948 & 3177 & 7249 & 10907 & 12317 \\
\hline PS 18799 & 14154 & 4083 & 8035 & 11792 & 13523 \\
\hline
\end{tabular}

being operated under similar conditions. Both groups of vehicles were fueled up by petrol coming from the same source. Each of the oils was applied randomly to five cars.

Oil sampling is of particular importance in such studies because the samples must be representative. This can be achieved, not only by ensuring appropriate and regular sampling procedure, but also by setting a proper sampling frequency. Due to the problems with regular collection of the samples after a certain number of kilometers traveled, a specific period of time was selected at which the sampling would be performed. All samples were collected and examined on a quarterly basis, starting with fresh oil and then after 3, 6, 9 and 12 months. At 3 and 6 months as many as 25 oil samples were taken, whereas at 9 and 12 months -23 (due to the decommissioning of the two vehicles). In total, after 12 months, 96 samples were collected.

The kinematic viscosity was measured at $40^{\circ} \mathrm{C}$ and $100^{\circ} \mathrm{C}$ in all samples, including fresh oil, and it was determined in accordance with the EN ISO 3104 using the Ubbelohde capillary 


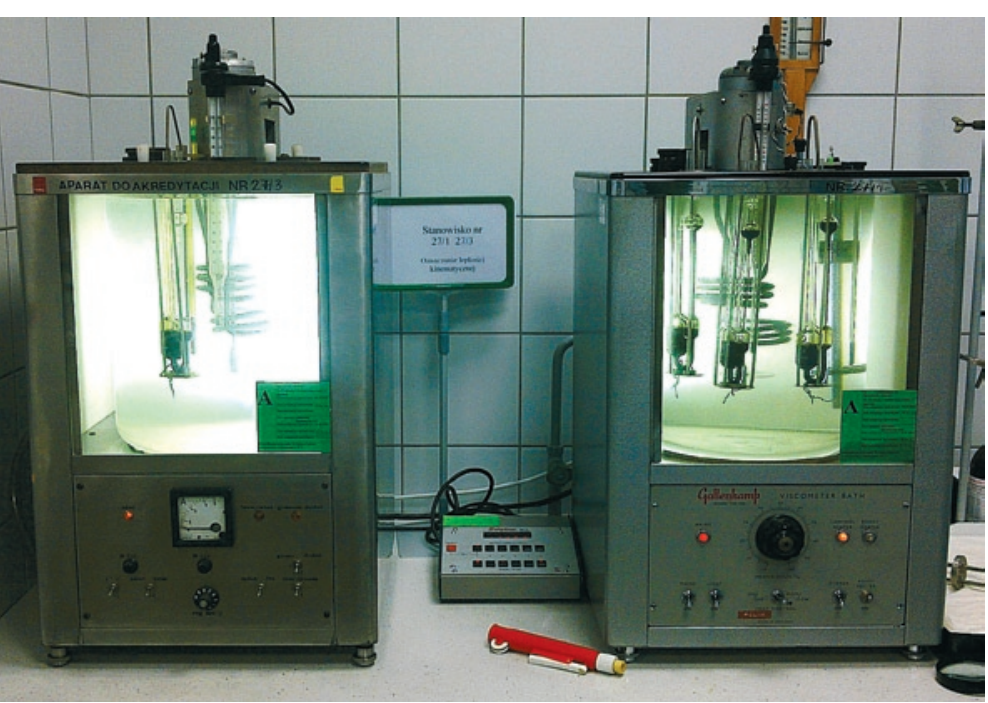

Fig. 1. The workstation used to measure the kinematic viscosity; Department of Performance Testing, Oil and Gas Institute in Kraków Source: Own elaboration viscometer (the size $2 \mathrm{C}$; range $60-300 \mathrm{~mm}^{2} \cdot \mathrm{s}^{-1}-$ temp. $40^{\circ} \mathrm{C}$, and the size $1 \mathrm{~B}$; range $10-50 \mathrm{~mm}^{2} \cdot \mathrm{s}^{-1}-$ temp. $\left.100^{\circ} \mathrm{C}\right)$. The lab workstation used to measure the kinematic viscosity at $40^{\circ} \mathrm{C}$ and $100^{\circ} \mathrm{C}$ is presented in Fig. 1.

All measurements were repeated three times and the results were statistically analyzed using the Statistica 10 software. Initially, the data was fitted to the linear regression model, estimated using the maximum likelihood method within the scope of socalled general least squares method. The use of that method made it possible to include in the process of estimation theoretically reasonable assumptions about the correlation of the next consecutive time measurements of the oil coming from the same vehicle.

It was assumed that the random component in the regression model is subject to continuous process of the first-order auto-regression. However, in the course of further studies, the results of the sensitivity analysis demonstrated that the use of the above-mentioned apparatus of advanced statistical analysis changed the outcome only minimally compared to the classical model of the normal linear regression. As a result, in order to simplify the presentation and to facilitate the interpretation of results, linear regression models were estimated using the classical least squares method.

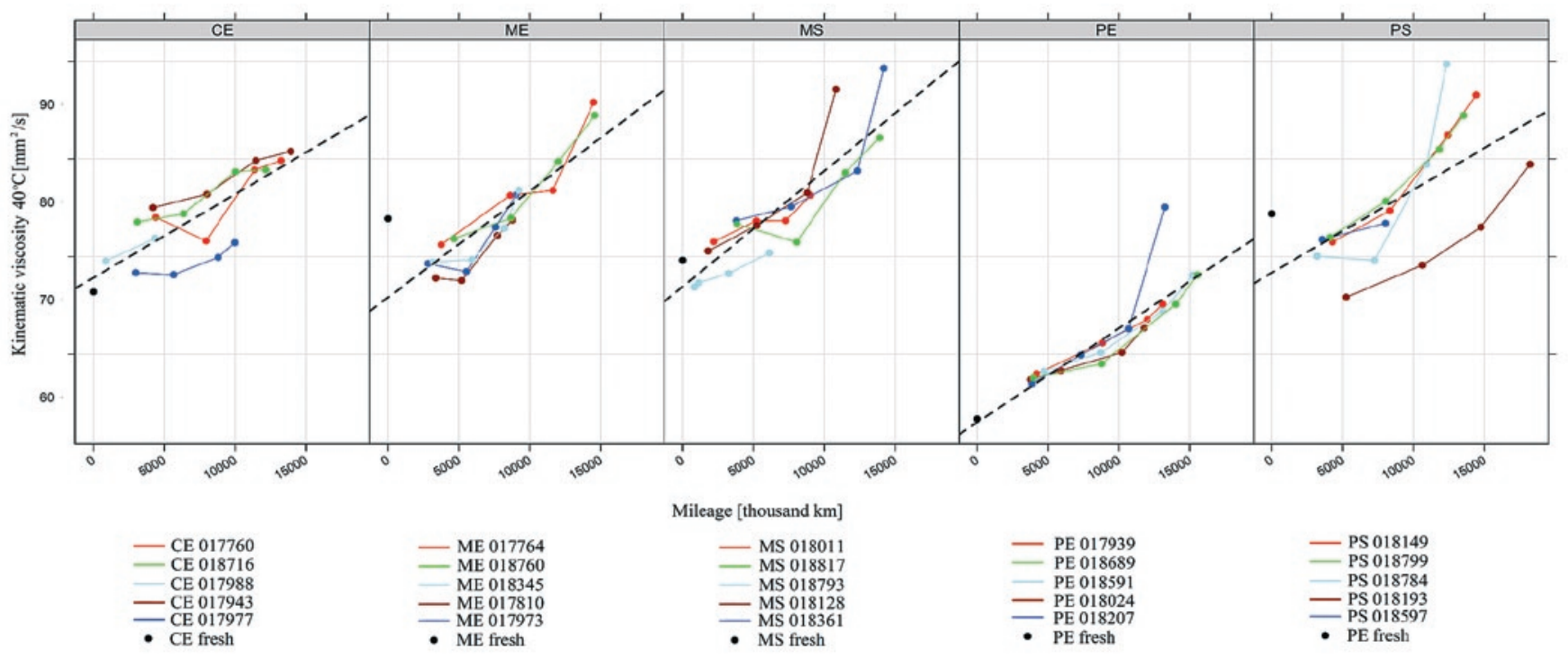

Fig. 2. Changes in kinematic viscosity of engine oils tested at $40^{\circ} \mathrm{C}$. Source: Own elaboration

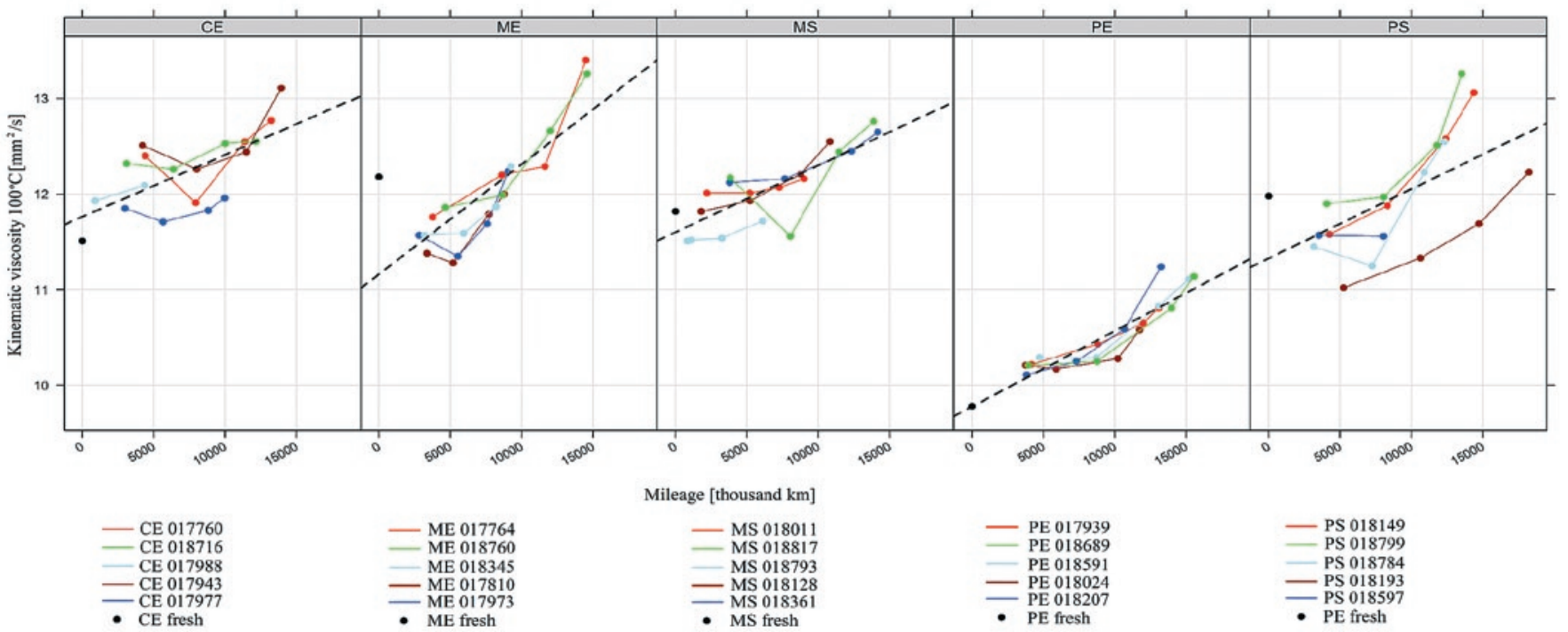

Fig. 3. Changes in kinematic viscosity of engine oils tested at $100^{\circ} \mathrm{C}$. Source: Own elaboration 


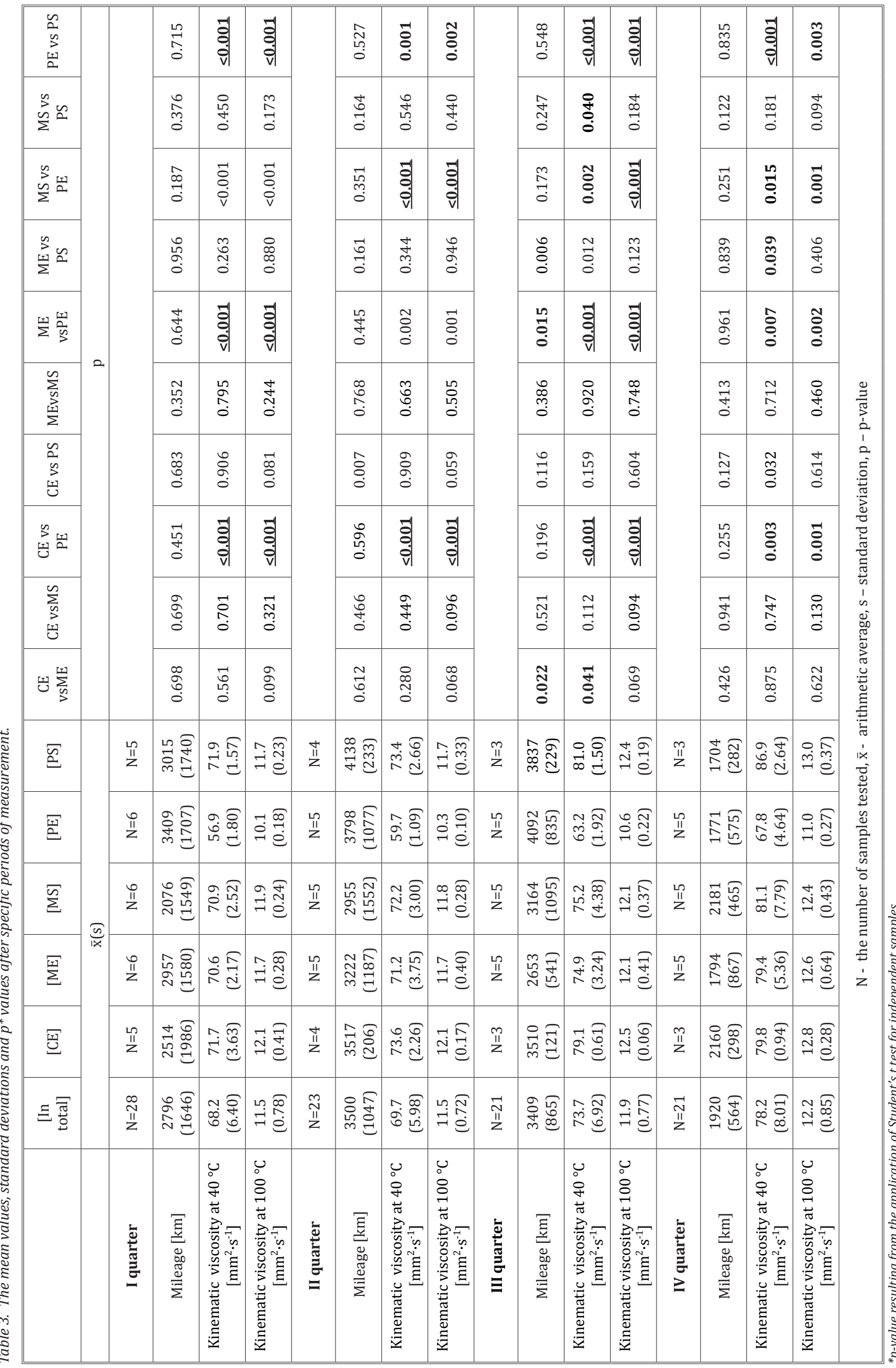


Table 4. The mean values, standard deviations and $p^{*}$ values for kinematic viscosity $40{ }^{\circ} \mathrm{C}$ and $100{ }^{\circ} \mathrm{C}$.

\begin{tabular}{|c|c|c|c|c|c|c|c|c|c|c|}
\hline & \multirow{3}{*}{ Oil group } & [quarter 1] & [quarter 2] & \multirow[b]{3}{*}{$\mathrm{p}$} & [quarter 2] & [quarter 3] & & [quarter 3] & [quarter 4] & \multirow[b]{3}{*}{$\mathrm{p}$} \\
\hline & & $\mathrm{N}=5$ & $\mathrm{~N}=4$ & & $\mathrm{~N}=4$ & $\mathrm{~N}=3$ & & $\mathrm{~N}=3$ & $\mathrm{~N}=3$ & \\
\hline & & \multicolumn{2}{|c|}{$\overline{\mathrm{x}}(\mathrm{s})$} & & \multicolumn{2}{|c|}{$\overline{\mathrm{x}}(\mathrm{s})$} & $\mathrm{p}$ & \multicolumn{2}{|c|}{$\overline{\mathrm{x}}(\mathrm{s})$} & \\
\hline \multirow{2}{*}{$\mathrm{CE}$} & Viscosity at $40^{\circ} \mathrm{C}$ & $71.7(3.63)$ & $73.6(2.26)$ & 0.647 & $73.6(2.26)$ & $79.1(0.61)$ & 0.050 & $79.1(0.61)$ & $79.8(0.94)$ & 0.106 \\
\hline & Viscosity at $100 \stackrel{\circ}{ } \mathrm{C}$ & $12.1(0.41)$ & $12.1(0.17)$ & 0.331 & $12.1(0.17)$ & $12.5(0.06)$ & 0.123 & $12.5(0.06)$ & $12.8(0.28)$ & 0.255 \\
\hline \multirow{2}{*}{ PS } & Viscosity at $40^{\circ} \mathrm{C}$ & $71.9(1.57)$ & $73.4(2.66)$ & 0.115 & $73.4(2.66)$ & $81.0(1.50)$ & 0.028 & $81.0(1.50)$ & $86.9(2.64)$ & 0.111 \\
\hline & Viscosity at $100 \stackrel{\circ}{ } \mathrm{C}$ & $11.7(0.23)$ & $11.7(0.33)$ & 0.725 & $11.7(0.33)$ & $12.4(0.19)$ & 0.029 & $12.4(0.19)$ & $13.0(0.37)$ & 0.054 \\
\hline & & $\mathrm{N}=6$ & $\mathrm{~N}=5$ & & $\mathrm{~N}=5$ & $\mathrm{~N}=5$ & & $\mathrm{~N}=5$ & $\mathrm{~N}=5$ & \\
\hline & & \multicolumn{2}{|c|}{$\overline{\mathrm{x}}(\mathrm{s})$} & $\mathrm{p}$ & \multicolumn{2}{|c|}{$\overline{\mathrm{x}}(\mathrm{s})$} & $\mathrm{p}$ & \multicolumn{2}{|c|}{$\overline{\mathrm{x}}(\mathrm{s})$} & $\mathrm{p}$ \\
\hline \multirow{2}{*}{ ME } & Viscosity at $40{ }^{\circ} \mathrm{C}$ & $70.6(2.17)$ & $71.2(3.75)$ & 0.300 & $71.2(3.75)$ & $74.9(3.24)$ & 0.014 & $74.9(3.24)$ & $79.4(5.36)$ & 0.022 \\
\hline & Viscosity at $100{ }^{\circ} \mathrm{C}$ & $11.7(0.28)$ & $11.7(0.40)$ & 0.657 & $11.7(0.40)$ & $12.1(0.41)$ & 0.019 & $12.1(0.41)$ & $12.6(0.64)$ & 0.018 \\
\hline \multirow{2}{*}{ MS } & Viscosity at $40{ }^{\circ} \mathrm{C}$ & $70.9(2.52)$ & $72.2(3.00)$ & 0.294 & $72.2(3.00)$ & $75.2(4.38)$ & 0.071 & $75.2(4.38)$ & $81.1(7.79)$ & 0.038 \\
\hline & Viscosity at $40{ }^{\circ} \mathrm{C}$ & $11.9(0.24)$ & $11.8(0.28)$ & 0.531 & $11.8(0.28)$ & $12.1(0.37)$ & 0.117 & $12.1(0.37)$ & $12.4(0.43)$ & 0.008 \\
\hline \multirow{2}{*}{ PE } & Viscosity at $40{ }^{\circ} \mathrm{C}$ & $56.9(1.80)$ & $59.7(1.09)$ & 0.009 & $59.7(1.09)$ & $63.2(1.92)$ & 0.011 & $63.2(1.92)$ & $67.8(4.64)$ & 0.080 \\
\hline & Viscosity at $100{ }^{\circ} \mathrm{C}$ & $10.1(0.18)$ & $10.3(0.10)$ & 0.203 & $10.3(0.10)$ & $10.6(0.22)$ & 0.016 & $10.6(0.22)$ & $11.0(0.27)$ & 0.014 \\
\hline
\end{tabular}

$\mathrm{N}$ - the number of samples tested, $\overline{\mathrm{x}}$ - arithmetic average, $\mathrm{s}$ - standard deviation , $\mathrm{p}$ - $\mathrm{p}$-value

${ }^{*} p$-value resulting from the application of Student's $t$ test for independent samples

Source: Own elaboration

\section{Results and discussion}

The test results for the kinematic viscosity in the analyzed periods are shown graphically in Figure 2 and 3. All test oils corresponded with viscosity grade $5 \mathrm{~W}-30$, at which, according to the classification SAE J300-2013, kinematic viscosity at $100^{\circ} \mathrm{C}$ should be in the range of $9.3-12.5 \mathrm{~mm}^{2} \cdot \mathrm{s}^{-1}$. Although all oils have met the requirements, it is clear that the oil sample PE was characterized by the lowest values of kinematic viscosity.

The analysis of changes in kinematic viscosity of motor oils during operation gives rise to the conclusion that the kinematic viscosity of oil samples CE, MS and PE at 40 and $100^{\circ} \mathrm{C}$ showed an upward trend, which is a clear indication of the intensity of oxidation processes. In the case of oil samples ME and PS, the reverse trend was observed, i.e. the kinematic viscosity decreased from its baseline level.

The decrease in viscosity of engine oil in the initial operation phase under the shear of viscosity modifier was not compensated by the increase in viscosity resulting from the compaction of oil degradation products. The situation has changed diametrically between 10,000$15,000 \mathrm{~km}$, when the degradation process dramatically accelerated, thus setting the maximums for all tested oils.

It should also be noted that the oil sample PE which was characterized by the lowest value of the kinematic viscosity, at the mileage level of $15,000 \mathrm{~km}$, eventually reached the figures corresponding with the initial ones for the remaining oils analyzed. Thus, the oil sample $\mathrm{PE}$ after a year of operation has a kinematic viscosity similar, or equal, to the fresh oil samples CE and MS.

Of the 23 analyzed oils, from the third to the fourth quarter, the highest percentage increase in viscosity at $40^{\circ} \mathrm{C}$ was recorded for the following oil samples: PE 018207 by $20 \%$ (from 62.6 to $75.1 \mathrm{~mm}^{2} \cdot \mathrm{s}^{-1}$ ), MS $01812814 \%$ (from 76.5 to 87.1 ), MS 018361 by $13 \%$ (from 78.8 to 89.3), PS $01878413 \%$ (from 79.5 to 89.7) and ME $01776412 \%$ (from 76.8 to 85.8 ). And an increase in viscosity at $100^{\circ} \mathrm{C}$ for oil samples: ME $01776414 \%$ (from 11.8 to 13.4), PS $01814913 \%$ (from 11.6 to 13.1) and ME $01876012 \%$ (from 11.9 to 13.3).

The second group of samples i.e. PS 018193 and CE 017977 should be analyzed separately in the future. Clearly, a change in operating con- ditions influenced the changes in viscosity. The viscosity figures in the second group of samples were lower by about $10 \%$ throughout the entire test period in relation to oils used in the first group of samples.

After analyzing the changes in viscosity at $40^{\circ} \mathrm{C}$, it can be concluded that a relatively narrow range of variation was retained by the oil samples CE. In this group, in all four cases, the kinematic viscosity was maintained within the range of 66.4 to $80.8 \mathrm{~mm}^{2} / \mathrm{s}$. In contrast, for the kinematic viscosity at $100^{\circ} \mathrm{C}$ the narrowest range of variation was retained by the oil sample PE (from 9.8 to $11.2 \mathrm{~mm}^{2} \cdot \mathrm{s}^{-1}$ ).

Moreover, it is worth noting that the curves of changes in viscosity are of similar shape in three cases: oil sample MS, PS and ME. The kinematic viscosity at $40^{\circ} \mathrm{C}$ in these groups after about 14,000 $\mathrm{km}$ traveled in relation to the kinematic viscosity of fresh oil has increased by $23 \%, 17 \%$ and $15 \%$ respectively.

The results of the viscosity at $100^{\circ} \mathrm{C}$ give rise to the conclusion that the kinematic viscosity of oil samples CE, ME, MS and PS, after about $12,000 \mathrm{~km}$ traveled rises to levels corresponding to the class of viscosity $5 \mathrm{~W}-40$. Only oils designated as PE remain in the viscosity grade $5 \mathrm{~W}-30$ during entire life-cycle.

Table 3 presents the descriptive characteristics of the tested engine oils in different periods of measurement. The limit value level of significance was set at 0.05 . Below this value, the results obtained were evaluated as statistically significant (values are distinguished in bold). The p-values of less than 0.01 were considered highly significant (values are distinguished in bold and underlined).

Analyzing the individual variables, as in Table 3, it was found that after the first three months of operation the greatest number of statistically significant differences between the mean values was found in the pairs of oils with the oil sample PE. It showed lower average viscosity value compared with other oils. The analysis of the variable - mileage - did not show any statistically significant differences.

After three periods of measurement, a continuation of previously discussed trend was visible, i.e. the greatest number of statistically significant differences between the mean values was found in the pairs of oils with the oil sample PE. After six months of operation, the most homogeneous in terms of the analyzed variables were oil sample pairs CE - ME and MS - ME. 
After the third quarter, the analyzed variable - kinematic viscosity at $40^{\circ} \mathrm{C}$ and $100^{\circ} \mathrm{C}$ - showed that the statistical significance level lower than or equal to 0.001 , makes the previously described comparisons (pairs of oils containing oil sample PE) highly significant. In terms of the variable - mileage - it was noted that statistically significant differences between the mean values were found in the pairs of oils with the oil sample ME (except for ME - MS). This is due to the fact that the group of oil samples ME had the lowest average mileage in the third period of the test $-2,653 \mathrm{~km}$. This result is perhaps statistically significant but essentially irrelevant. The standard deviation of mileage for ME oils in the study is on a low level (about $541 \mathrm{~km}$ ) - which indicates a highly uniform mileages of vehicles equipped with these oils.

After the last measurement period, no statistically significant differences between the arithmetic means have been observed. After analyzing all four measurement periods, it can be noted that in some of them the comparisons almost reached statistical significance, suggesting the potential existence of differences. Such observation may be of interest in terms of possible future studies.

When analyzing the contents of Table 4, it can be concluded that some of the differences in the consecutive measuring periods were statistically significant, e.g. the kinematic viscosity measured at $40^{\circ} \mathrm{C}$

Table 5. The results of the estimation of linear regression model for kinematic viscosity $\left(100^{\circ} \mathrm{C}\right)$.

\begin{tabular}{||c|c|c|c||}
\hline A & B & p & Se \\
\hline \multicolumn{5}{|c||}{ CE } \\
\hline 11.846 & 0.067 & 0.001 & 0.247 \\
\hline \multicolumn{5}{|c||}{ ME } \\
\hline 11.162 & 0.115 & 0.000 & 0.361 \\
\hline \multicolumn{5}{|c|}{ PE } \\
\hline 9.776 & 0.079 & 0.000 & 0.224 \\
\hline \multicolumn{5}{|c|}{ PS } \\
\hline 11.233 & 0.105 & 0.001 & 0.394 \\
\hline
\end{tabular}

Source: Own elaboration

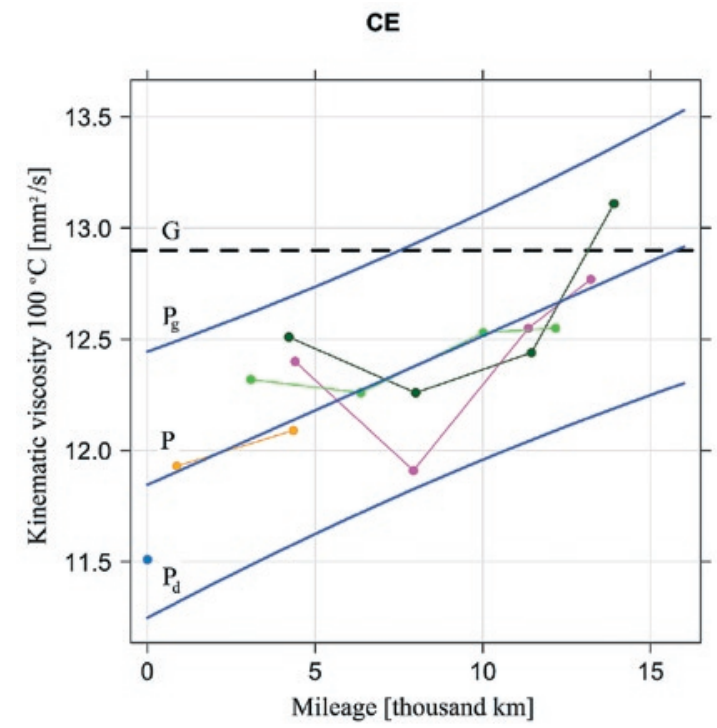

Fig. 4. Empirical data and single point predictions of mileage in the range (0-16) thousand kilometers (kinematic viscosity at $100^{\circ} \mathrm{C}$ ) $P$-single point predictive; $P d$ - lower limit of the $95 \%$ prediction interval; Pg-upper limit of the 95\% prediction interval; $G$ - the limit value and $100^{\circ} \mathrm{C}$ in the group of oil samples ME showed statistically significant differences between the second and third period, and between the third and the fourth, which may potentially indicate the acceleration of the upward trend for the average values of this parameter.

In the case of the oil samples PS, the kinematic viscosity showed a statistically significant difference only between the second and the third period, which may potentially indicate a sinusoidal curve form of
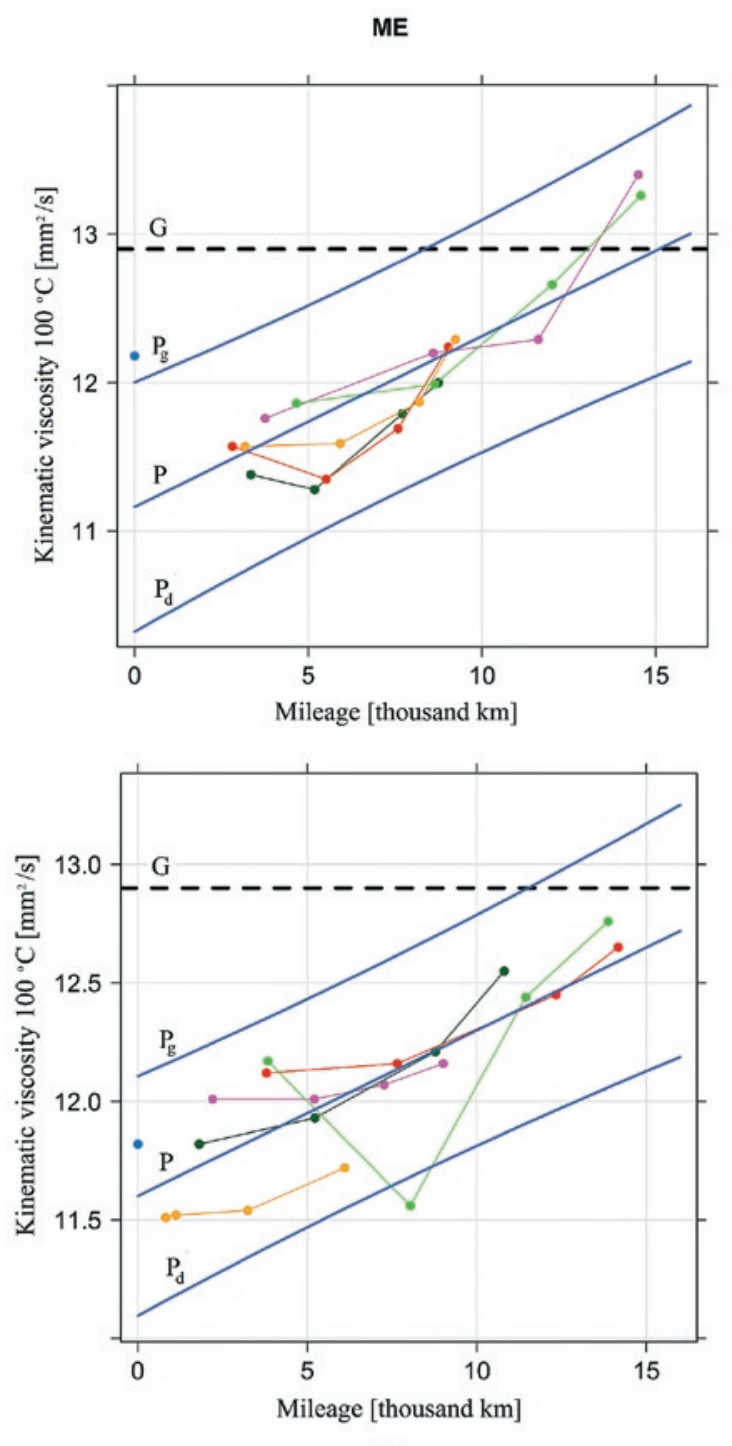

PE

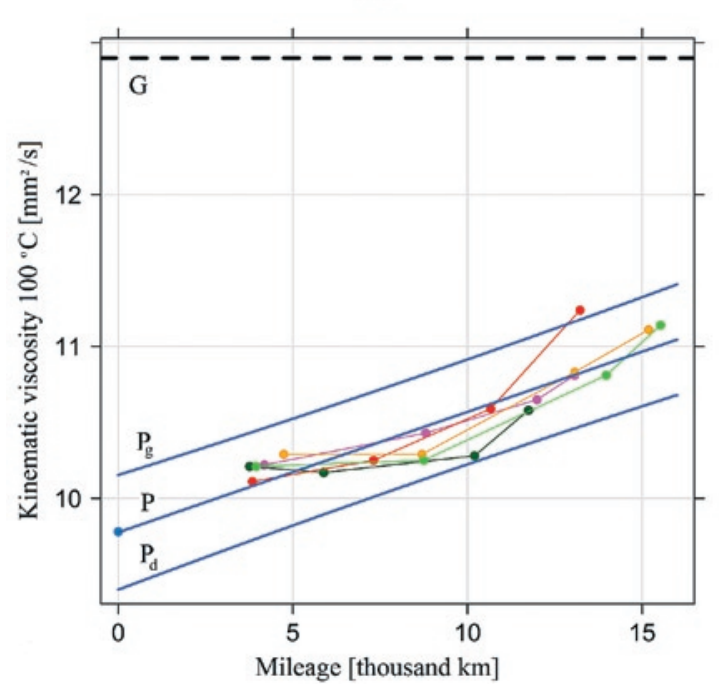


PS

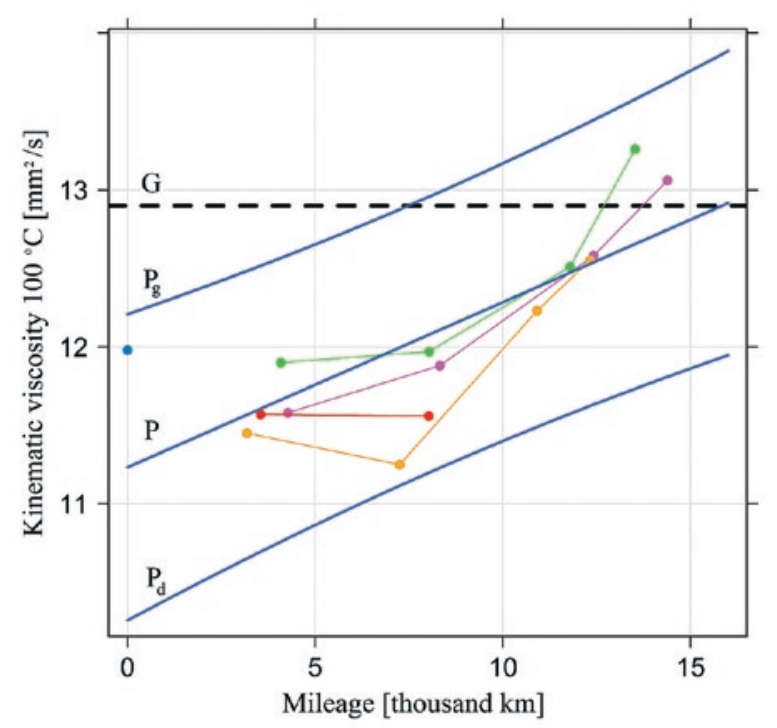

Fig. 4. (continued) Empirical data and single point predictions of mileage in the range (0-16) thousand kilometers (kinematic viscosity at $100^{\circ} \mathrm{C}$ ) $P$-single point predictive; $P d$-lower limit of the $95 \%$ prediction interval; $P g$ - upper limit of the $95 \%$ prediction interval; $G$ - the limit value Source: Own elaboration

the average values for this parameter. In the case of kinematic viscosity of oil samples $\mathrm{CE}$, both at $40^{\circ} \mathrm{C}$ and $100^{\circ} \mathrm{C}$, no significant differences were observed for any of the studied consecutive periods. It should be noted, however, that in the case of kinematic viscosity at $40^{\circ} \mathrm{C}$, comparing the second period with the third, the differences in the mean values were very close to reaching the statistical significance $(p=0.05)$.

\section{Modeling changes in the parameter values of engine oils}

In the first step of modeling the changes in kinematic viscosity at $100^{\circ} \mathrm{C}$ the acceptable limit value was determined $[9,12]$, then on the basis of collected empirical material the visual assessment of the relationships between the mileage and the changes in the oil properties was performed for every oil type. It was assumed that the linear relationship was adequate.

Table 5 presents the results of estimations. It specifies the absolute term values (A), slope coefficients (B), contains probability test for the hypotheses proclaiming slope coefficients' value equal to $0(\mathrm{p})$, and the residual standard deviations (Se).

It can be observed that each of the ratings of the slope coefficients was significantly different from zero (all $p<0.05$ ). The slope coefficient indicates the expected (average) change in the parameter with the increase in the mileage of $1000 \mathrm{~km}$. Thus, the positive slope coefficients indicate a positive relationship between the mileage and the average parameter values while negative slope coefficients indicate a negative relationship between the mileage and the average parameter values.

The estimated regression equation, with the form of $\mathrm{Y}=\mathrm{A}+\mathrm{B} * \mathrm{X}$, enables to calculate average predictive values for parameters $(\mathrm{Y})$ and given mileage $(\mathrm{X})$. The adequate values of $\mathrm{A}$ and $\mathrm{B}$ are shown in Table 5. The predictions will be less affected by error within the observed values of mileage, whereas the extrapolation or prediction making for much higher or lower mileage figures than investigated in this study may carry a higher risk of error, since the form of the relationship between the mileage and the test parameter outside the data is not necessarily of the same form and nature.
Figure 4 presents the collected empirical data and predictive values of mileage between $0-16$ thousand kilometers (the blue line in the center). The predictive values, like any other values estimated on the basis of empirical data, carry a risk of error. In order to quantify the level of possible error, the curves defining the limits of $95 \%$ prediction interval (curves $\mathrm{P}_{\mathrm{d}}$ and $\mathrm{P}_{\mathrm{g}}$ ) are also included in the chart. The black dotted horizontal line stands for accepted limit values (line $G$ ). At the point of intersection of the line $P$ with the line $G$ the mileage value can be found at which the average parameter value would exceed the threshold value; this is a so called reversed prediction value. The mileage value read as the points of intersection of the line $G$ with the curves $P_{d}$ and $P_{g}$ indicate the $95 \%$ confidence interval (also called calibration interval) for the mileage value, at which the threshold value is exceeded for a hypothetical individual measurement of the tested parameter.

After analyzing the predictive values of mileage between $0-16$ thousand kilometers for the kinematic viscosity at $100^{\circ} \mathrm{C}$ parameter (Fig. 4), it was found that the critical value was first exceeded by the group of oil samples ME, followed by the CE and PS ex aequo. A distinctively low kinematic viscosity compared to other oils, continuing at the acceptable limits up to the mileage of $40000 \mathrm{~km}$ (extrapolation), was observed in the case of oils from the PE group. Noteworthy, are also very narrow prediction ranges for oils in this group.

\section{Final conclusions}

This study focuses primarily on the description of changes in kinematic viscosity of engine oils during operation. The results of research conducted on a fleet of vehicles under actual working conditions may facilitate decision-making regarding the service life of engine oils and the intervals between oil changes. The main conclusions of this study are as follows:

Three of the five types of oils i.e. CE, MS and PE have shown, since the beginning of the test, an increase in kinematic viscosity at 40 and $100^{\circ} \mathrm{C}$ as compared to the baseline levels, which may indicate oxidation processes occurring in oils.

The curves of changes in these oils are of similar shape, and the kinematic viscosity in these groups after 12 months, relative to the kinematic viscosity of fresh oil, increased by $20 \%, 16 \%, 27 \%$ (temp. $40^{\circ} \mathrm{C}$ ) and $11 \%, 5 \%, 12 \%$ (temp. $100^{\circ} \mathrm{C}$ ), respectively. In the case of two oils - ME and PS - an initial decrease in viscosity from baseline level up to the mileage of about 10 thousand $\mathrm{km}$ was observed, then the viscosity started to increase. This can be explained by the shear of viscosity additives in the initial period of operation. The curves of viscosity changes for these oils have similar shape and the change in viscosity, as compared to the fresh oil, was as follows: $8 \%$ and $14 \%$ (temp. $40^{\circ} \mathrm{C}$ ), $4 \%$ and $8 \%$ (temp. $100^{\circ} \mathrm{C}$ ), respectively. It must be, therefore, concluded that the change in viscosity will strongly depend on the formulation of oil by the manufacturer. A proper selection of oil formulation for fleet vehicles operated in similar conditions will have an impact on the degradation of oil.

Statistical analysis assisted in confirming the significance of changes in viscosity between oil type PE and other oils. In contrast, only some of the differences in the consecutive measuring periods proved to be statistically significant.

The obtained results have led to the development of a statistical model using basic mathematical model - a linear function. The resulting model, based on the change in kinematic viscosity of in-service engine oils at $100^{\circ} \mathrm{C}$ can be used to predict the behavior of the engine oil during operation.

It should be noted, however, that in order to obtain the full picture of the changes taking place in the oil, it is advisable to interpret the kinematic viscosity figures together with the dynamic viscosity (HTHS) ones, as well as with the degree of oxidation and acid 
number. These properties can affect the reliability of the engine, and therefore it is important to continue to investigate the processes of degradation of engine oils.

\title{
Acknowledgements
}

The publication was funded by appropriations of the Faculty of Commodity Science, Cracow University of Economics, within the framework of grants to maintain the research potential. All laboratory tests for this study were conducted at the Oil and Gas Institute in Kraków - the National Research Institute. The authors wish to thank the Director of the Oil and Gas Institute: Prof. Maria Ciechanowska, PhD. Eng. and acting as Deputy Director for Oil Technology: MSc Wiesława Urzędowska, for the opportunity to perform the tests.

\section{References}

1. Agoston A, Ötsch C, Jakoby B. Viscosity sensors for engine oil condition monitoring-Application and interpretation of results. Sensors Actuators A Phys. 2005; 121(2): 327-32. https://doi.org/10.1016/j.sna.2005.02.024.

2. Balabin R M, Safieva R Z. Motor oil classification by base stock and viscosity based on near infrared (NIR) spectroscopy data. Fuel 2008; 87(12): 2745-2752, https://doi.org/10.1016/j.fuel.2008.02.014.

3. Bassbasi M, Hafid A, Platikanov S, Tauler R, Oussama A. Study of motor oil adulteration by infrared spectroscopy and chemometrics methods. Fuel 2013; 104: 798-804, https://doi.org/10.1016/j.fuel.2012.05.058.

4. Brouwer M, D, Gupta L, A., Sadeghi F, Peroulis D, Adams D. High temperature dynamic viscosity sensor for engine oil applications. Sensors Actuators A Phys. 2012; 173(1): 102-107.

5. Inayatullah O, Jamaludin N, Ali A, Nor M J M. Application of acoustic emission technique to observer the engine oil's viscosity. 2nd International Conference on Instrumentation Control and Automation. IEEE 2011: 344-348.

6. Jakoby B, Scherer M, Buskies M, Eisenschmid H. An automotive engine oil viscosity sensor. IEEE Sens J. 2003; 3(5): 562-568, https://doi. org/10.1109/JSEN.2003.817164.

7. Karpovich I A, Odzhayev V B, Azarko I I, Jankovsky ON. Universal device for motor-oil quality control. 11th International Conference Microwave and Telecommunication Technology Conference Proceedings IEEE Cat No01EX487. 2001.

8. Kim Y, Kim N Y, Park S Y, Lee D-K, Lee J H. Classification and individualization of used engine oils using elemental composition and discriminant analysis. Forensic Sci Int. 2013; 230 (1-3): 58-67, https://doi.org/10.1016/j.forsciint.2013.01.013.

9. Kral J, Konecny B, Madac K, Fedorko G, Molnar V. Degradation and chemical change of longlife oils following intensive use in automobile engines. Measurement 2014; 50: 34-42, https://doi.org/10.1016/j.measurement.2013.12.034.

10. Kumbar V, Votava J. Differences in engine oil degradation in spark-ignition and compression-ignition engine. Eksploatacja i Niezawodnosc - Maintenance and Reliability 2014; 16(4): 622-628.

11. Kuranc A. Exhaust emission test performance with the use of the signal from air flow meter. Eksploatacja i Niezawodnosc - Maintenance and Reliability 2015; 17 (1): 129-134, https://doi.org/10.17531/ein.2015.1.17.

12. Souza de Carvalho M J, Rudolf Seidl P, Pereira Belchior C R, Ricardo Sodré J. Lubricant viscosity and viscosity improver additive effects on diesel fuel economy. Tribol Int. 2010; 43(12): 2298-2302, https://doi.org/10.1016/j.triboint.2010.07.014.

13. Urzędowska W, Stępień Z. Wybrane zagadnienia dotyczące zmian właściwości silnikowego oleju smarowego w eksploatacji. Nafta-Gaz. 2012; 12 (LX): 1102-1110.

14. Wang S. Engine oil condition sensor: method for establishing correlation with total acid number. Sensors Actuators B Chem. 2002; 86(2-3): 122-126, https://doi.org/10.1016/S0925-4005(02)00155-7.

15. Wang S S. A Physical Model for the Engine Oil Condition Sensor. Tribology Transactions. 2001: 11-6, https://doi. org/10.1080/10402000108982475.

16. Wolak A, Hornik S. Changes in funkcional properties of engine oils during exploitation - TBN. Current Trends in Commodity Science: Development and Assessment of Non-Food Products. 2015.

17. Wolak A, Janocha P. Zmiany właściwości użytkowych olejów silnikowych w warunkach eksploatacji - analizy FTIR, Nowoczesne środki smarowe do specjalistycznych zastosowań w urządzeniach przemysłowych, transporcie i komunikacji. Kraków: Instytut Nafty i Gazu Państwowy Instytut Badawczy 2015: 84-105.

18. Youngk R D. Automobile engine reliability, maintainability and oil maintenance. Annu Reliab Maintainab Symp 2000 Proc Int Symp Prod Qual Integr Cat No00CH37055; 2000: 94-99, https://doi.org/10.1109/rams.2000.816290.

19. Zając G, Szyszlak-Bargłowicz J, Słowik T, Kuranc A, Kamińska A. Designation of Chosen Heavy Metals in Used Engine Oils Using the XRF Method. Polish J Environ Stud. 2015; 2277-2283, https://doi.org/10.15244/pjoes/58781.

\author{
Artur WOLAK \\ Department of Industrial Commodity Science \\ Cracow University of Economics \\ ul. Sienkiewicza 4, 30-033 Kraków, Poland
}

\section{Grzegorz ZAJAC}

Department of Power Engineering and Transportation

Faculty of Production Engineering

University of Life Sciences in Lublin

ul. Głęboka 28, 20-612 Lublin, Poland

E-mail: artur.wolak@uek.krakow.pl,grzegorz.zajac@up.lublin.pl 